\title{
Water quality of a Central Himalayan lake, Lake Sattal, Uttarakhand
}

\author{
S. Inaotombi* and P.K. Gupta \\ Department of Zoology, D.S.B. Campus, Kumaun University, Nainital-263 002, (U. K.) India
}

\begin{abstract}
The present research was carried out in Lake Sattal, Central Himalaya, from 2011 to 2012 with the objectives to find out the changes in water quality of the lake in last 30 years and to determine the trophic status of the lake in order to decide the usefulness of the lake for human consumption and fish production. Lake Sattal is a warm monomictic water body with high DO concentration. About three decades ago, it was in oligotrophic state. Sixty times increase in the concentration of phosphorous as compared to previous study has been found. The increased concentration of phosphorous and nitrogen in water signify that the lake has become eutrophic. Occasional anoxia at mud-water interface was noticed during the investigation period which strongly suggests that the process of eutrophication has recently started. These could be attributed to changes in the land use patterns, extensive land clearance, agriculture and suburban development and other biotic activities in the catchment. At present, the lake can be exploited for fish production by artificial culture as the quality of water is suitable. The data on various parameters of water quality studied in the present investigation are also under the desirable limit for the human consumption after proper treatment.
\end{abstract}

Keywords: Desirable limit, Lake Sattal, Trophic status, Water quality.

\section{Introduction}

The Lake Sattal lies at about $1286 \mathrm{~m}$ above sea level at $29^{\circ} 20^{\prime} 52^{\prime \prime} \mathrm{N}$ latitude and $79^{\circ} 31^{\prime} 55^{\prime \prime} \mathrm{E}$ longitude. Lake Sattal is situated about $20 \mathrm{~km}$ far from Nainital. The word 'Sattal' is derived from the Hindi word, meaning seven lakes ('Sat' means seven and 'tal' means lake). The two basins of the lake form a V-shaped structure with different depths. The maximum depth of the eastern basin is $14 \mathrm{~m}$ while that of western basin is $20 \mathrm{~m}$ (Table 1.).

The combined length of both basins is $1300 \mathrm{~m}$ with the maximum width of $190 \mathrm{~m}$. The shoreline development is $3750 \mathrm{~m}$. The combined surface area of both the basins is $0.04 \mathrm{~km}^{2}$ and catchment area is $4.4 \mathrm{~km}^{2}$.

Alteration of landscape and waste discharge around the catchments of some lakes of Kumaun region were observed due to increasing population and intensifying tourist activities which lead to enhanced soil erosion and rapid sedimentation. Cultural eutrophication by input of nutrients through domestic effluents bared the signs of deterioration in water quality of lakes. Modern techniques have been used to control the internal ecological processes to maintain the health of lakes and to restore their status (Gupta and Gupta 2012). Undoubtedly, concerted study is needed to check the deterioration in water quality of lakes. In view of these, many studies have been carried out in Kumaun lakes (Pant et al. 1979, 1981, 1985 a ,b, c; Singh 1981; Singh et al. 1982; Sharma et al. 1982; Joshi 1983; Negi 1983; Gupta and Pant 1990, 1991; Purohit and Singh 1985; Pant and Joshi 1987; Raina and Vass 1993; Gupta and Shukla 1996; Gupta et at. 1999; Shukla and Gupta, 2001; Nagdali 2002; Nagdali and Gupta 2002, 2003; Gupta and Bhagat, 2004; Bhagat and Gupta 2005; Gupta et al. 2010; Gupta and Gupta 2012).

Although a huge amount of literature has accumulated on the limnology of Kumaun lakes, 
Table 1 Morphometric features and meteorological data of Lake Sattal.

\begin{tabular}{|l|c|}
\hline Parameters & Sattal \\
\hline Longitude & $79^{\circ} 31^{\prime} 55^{\prime}{ }^{\prime} \mathrm{E}$ \\
\hline Latitude & $29^{\circ} 20^{\circ} 52^{\prime} \mathrm{N}$ \\
\hline Altitude ( $\mathrm{m}$ asl) & 1286 \\
\hline Length (m) & 1300 \\
\hline Width (m) & 190 \\
\hline Maximum depth(m) & 20 \\
\hline Surface area (km²) & 0.04 \\
\hline Catchment area (km²) & 4.4 \\
\hline Shoreline (m) & 3750 \\
\hline $\begin{array}{l}\text { Water storage (live storage) } \\
\left.\text { (mm }{ }^{3}\right)\end{array}$ & $2,598,500$ \\
\hline Annual rainfall (mm) & 1,813 \\
\hline
\end{tabular}

these studies are mainly done on a few well known lakes. It is, therefore, necessary to initiate studies on remote lakes of Kumaun. Only fragmentary published information exists on the limnology of the Sattal Lake (Joshi 1983; Pant and Joshi 1987). Moreover, these studies were conducted about 30 years back. Since the environment and level of eutrophication are changing continuously, it could be expected that physico-chemical parameters of the lake would have been also changed with the passage of time. Therefore, the main purpose of this study was to determine the changes in water quality of the lake in last 30 years. Besides these, attempts have also been made to determine the trophic status of the lake in order to decide the usefulness of the lake for fish production. A discussion on the quality of water for human consumption and other uses has also been made in the paper.

\section{Materials and Methods:}

This research was carried out for a period of two and half years from June, 2010 to

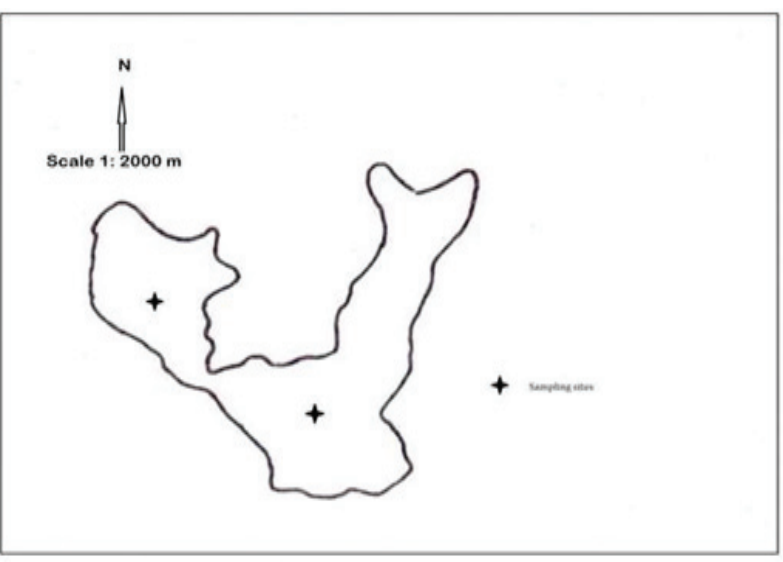

Fig. 1 Sketch map of Lake Sattal showing sampling stations.

December, 2012. The first six months were devoted to review the literature, selection of sites in the lake and standardization of the methods. The remaining two years, i.e. from January, 2011 to December, 2012 were used to collect data on various parameters of water quality. Sampling sites: Lake Sattal has two basins namely Eastern and Western basins. One sampling site in each basin was selected in order to collect data for physico-chemical parameters of water (Fig. 1).

Thermal stratification of the lake was studied seasonally to determine the circulation period of the lake. Likewise, to determine the anoxia at mud-water-interface, the concentration of dissolved oxygen (D.O) was measured occasionally at mud-water-interface in the profundal zone.

Sampling: Sampling for most of the parameters were done at the monthly interval, however, for some parameters, samples were collected seasonally. All the samplings were done between $9.00 \mathrm{am}$ and $11.00 \mathrm{am}$ throughout the study period. For the analysis of various physico-chemical parameters, water samples were directly taken by hand in wide mouth polyethylene bottles. The concentration of dissolved oxygen (by D.O. meter or by Winkler's method) and free carbon-dioxide (by filtration method) were determined at the site after collection. For the analysis of other parameters, samples were transported 
to the laboratory under ideal condition (Wetzel and Likens 1979).

Sample analysis: For the measurement of temperature, a good mercury thermometer was used. In addition, a D.O. meter (YSI, USA make, Model-550 A) with temperature sensor was used to measure temperature at various depths. $\mathrm{pH}$ of water was measured by Environmental Monitoring System of YSI, model $600-X L$ with data logger. The reading of dissolved oxygen was taken by YSI, USA make DO meter, model 550-A. However, sometimes Winkler's unmodified method (Welch 1948) was used to determine DO contents. Free carbon-dioxide $\left(\mathrm{CO}_{2}\right)$ was measured by titration method at the site itself. Transparency was measured by a black and white Secchi disc. The disc was $20 \mathrm{~cm}$ in diameter and was attached with graduated rope. The visibility of the Secchi disc was used to determine the transparency of the water.

Turbidity, Colour, Alkalinity, Hardness, Nitritenitrogen, Nitrate-nitrogen, Ammoniacal-nitrogen, Phosphorous, Iron, Manganese, Copper, Zinc, and Fluoride were measured by YSI photometer, US make (model 9100). This is an auto analyzer and uses its own reagents supplied with the equipment. The method of analysis and formulation of the reagents used, are based on APHA (2005). Biochemical oxygen demand (BOD) was determined by the method describe in APHA (2005). Three hundred (300) $\mathrm{ml}$ of the water samples were collected in a $300 \mathrm{ml}$ capacity BOD bottles. After adding reagents (APHA 2005), the samples were incubated at $20^{\circ} \mathrm{C}$ for 5 days in a BOD incubator. A laboratory $D O$ meter, YSI model-5100 attached with BOD probe measured the initial and final concentrations of oxygen. The formula used to calculate the BOD was as follows (APHA 2005):

$$
B O D \mathrm{mg} / \mathrm{l}=\frac{\mathrm{D}_{1}-D_{2}-\left(B_{1}-B_{2}\right)}{p} \times \mathrm{f}
$$

Where, $D_{1}=$ initial $\mathrm{DO}$ concentration in sample, $D_{2}=\mathrm{DO}$ concentration after 5 days of incubation of sample, $B_{1}=$ initial $\mathrm{DO}$ concentration in blank, $\mathrm{B}_{2}=\mathrm{DO}$ in blank after 5 days of incubation, $p=$ decimal fraction of sample used, and $f=$ ratio of blank to sample.

Presentation of data and statistics: The data presented are the mean values of three replicates, the standard deviation and mean values are shown in tables and graphs. Statistical analysis and computations were done with the help of software such as Microsoft Excel, XLSTAT version 2012, SPSS 16.0 version, and PAST 3.0, 2013 version in personal computer.

\section{Results and discussion}

Temperature: The mean monthly temperature of surface water in two basins of the lake during two years study is shown in Fig. 2. The pattern in seasonal variation was similar in both years. During first year (2011), the temperature varied from $15.8^{\circ} \mathrm{C}$ to $25.4^{\circ} \mathrm{C}$ and $16.2^{\circ} \mathrm{C}$ to $25.8^{\circ} \mathrm{C}$ in eastern and western basins, respectively. In the next consecutive year, it varied from 14.7 ${ }^{\circ} \mathrm{C}$ to $26.4^{\circ} \mathrm{C}$ and 14.8 to $26.3^{\circ} \mathrm{C}$ in eastern and western basins, respectively.

As it could be expected, the temperature followed the pattern similar to the ambient temperature. Thus, the minimum values were always recorded during winters and the maxima were noticed during summer. The vertical distribution of temperature was studied from January to June and again in December, 2011 to find out the thermal stratification and circulation period of the lake. It was noticed that the lake underwent circulation during January-February and remained thermally stratified during rest of the year. The vertical distribution of temperature during circulation (January, 2011) and stratification period (June, 2011) is indicated in Fig. 3.

As it is evident from the figure, the epilimnion extended from $0 \mathrm{~m}$ to $4 \mathrm{~m}$ depth. The metalimnion was $4 \mathrm{~m}$ thick and extended from 4 to $8 \mathrm{~m}$ water depth. The hypolimnion was comparatively thick and extended form $8 \mathrm{~m}$ to the deepest point of the lake.

Water transparency: The water transparency determined by Secchi disc, ranged from 


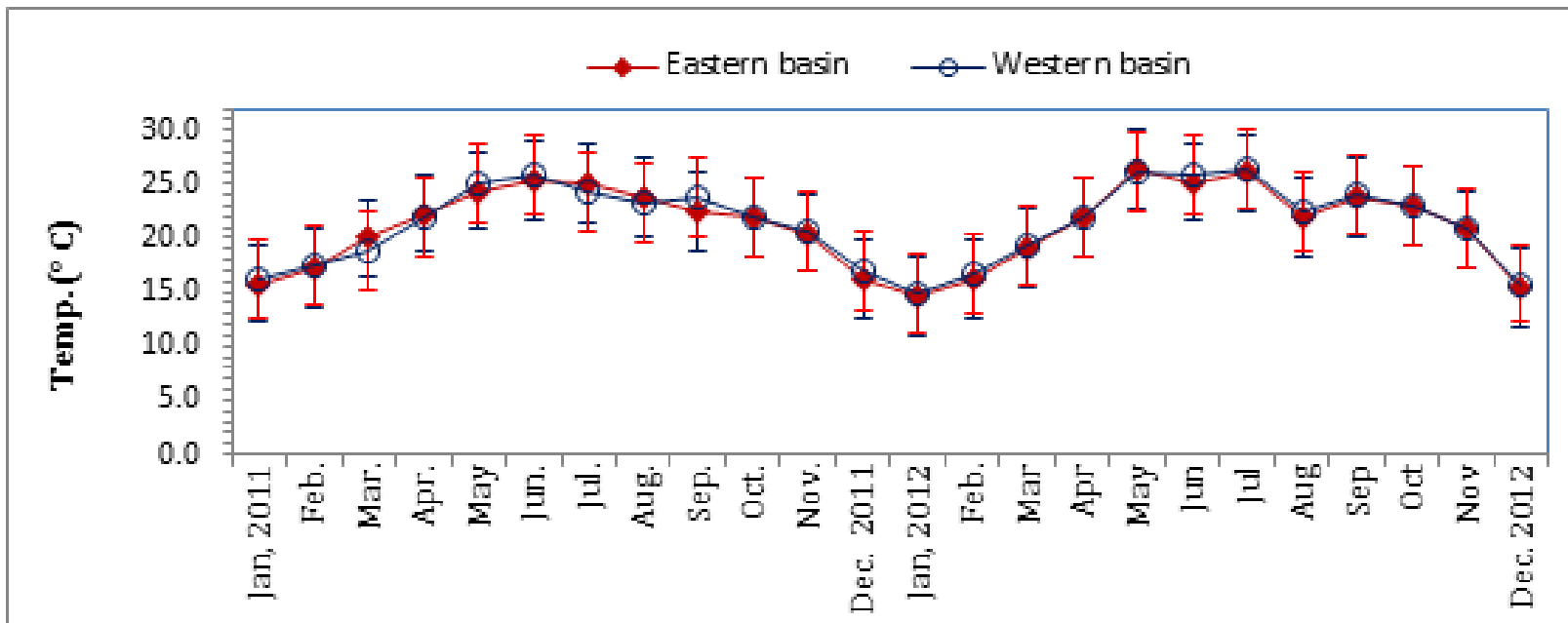

Fig. 2 Monthly variation in water temperature $\left({ }^{\circ} \mathrm{C}\right)$ in two basins of Lake Sattal during study the period (vertical bars indicate standard deviation of the mean).

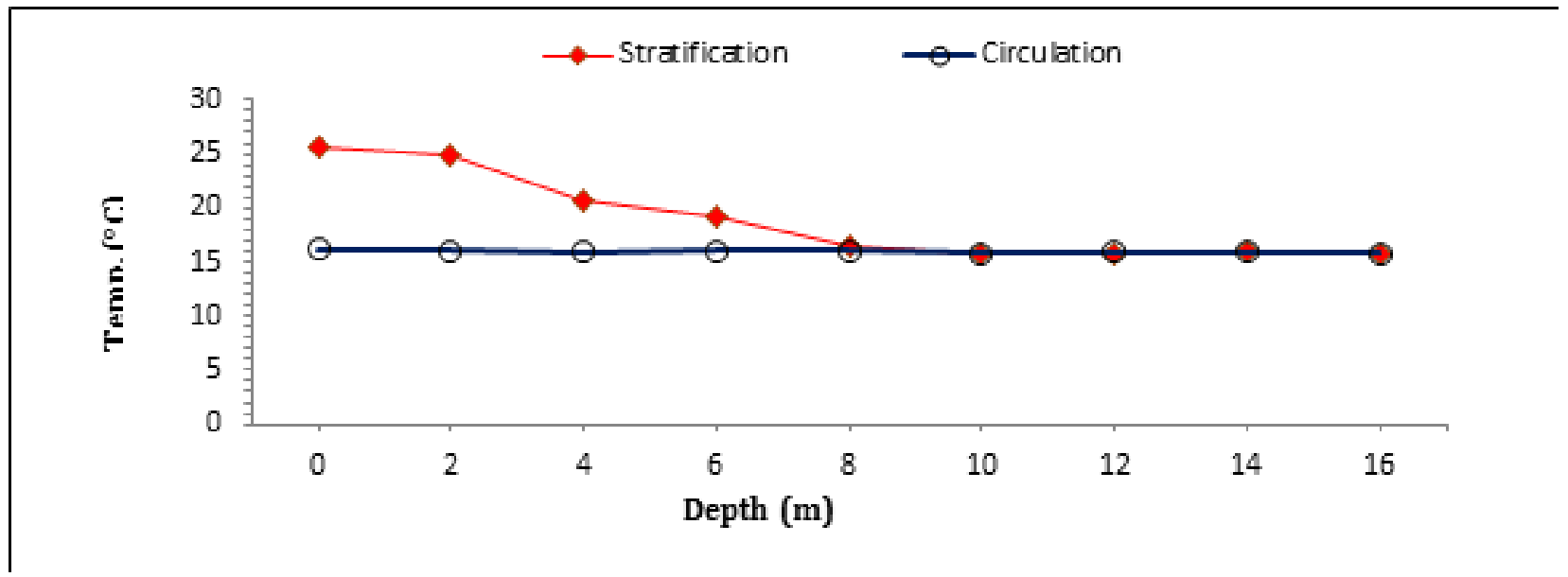

Fig. 3 Thermal curves during stratification (June, 2011) and circulation periods (January, 2012) in the western basin of Lake Sattal.

$1.6 \mathrm{~m}$ to $3.2 \mathrm{~m}$ in eastern basin and 1.1 to 3.0 $\mathrm{m}$ in western basin during the whole study period (Fig. 4). In general, the values were lower during the rainy season and higher during the summer season. Although, two basins showed differences in Secchi disc reading on monthly basis, there was no significant difference between biannual mean values of transparency of two basins $(2.3 \pm 0.5 \mathrm{~m}$ each in both basins).
Turbidity: The fluctuation in turbidity was quite high. It ranged from 0 to 16 FTU in both basins during the whole study period (Fig. 5). On two years mean basis, the value of turbidity was greater in eastern basin (6.9 $\pm 5.45 \mathrm{FTU})$ as compared to western basin (6.0 $44.23 \mathrm{FTU})$; however, the two values were not significantly different. In general, the values of turbidity were lower during dry season and higher during the rainy season. 


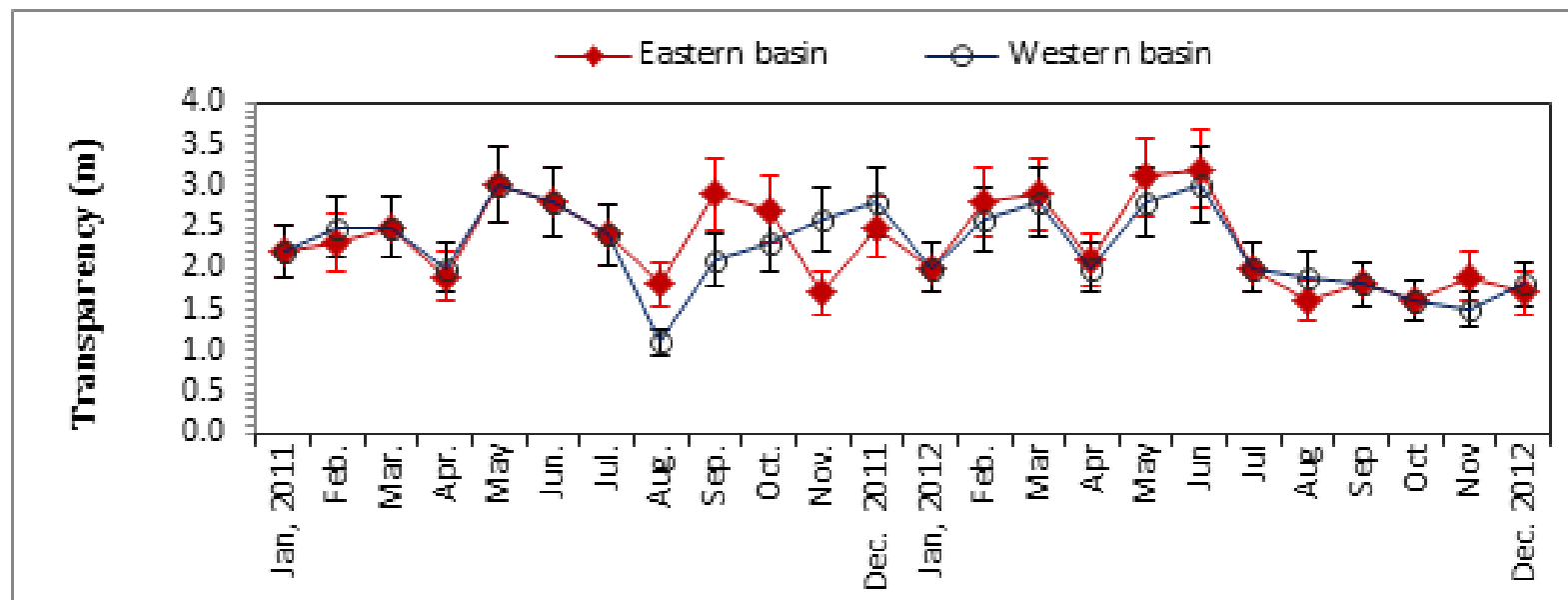

Fig. 4 Monthly variation in transparency $(\mathrm{m})$ in two basins of Lake Sattal during the study period (vertical bars indicate standard deviation of the mean).

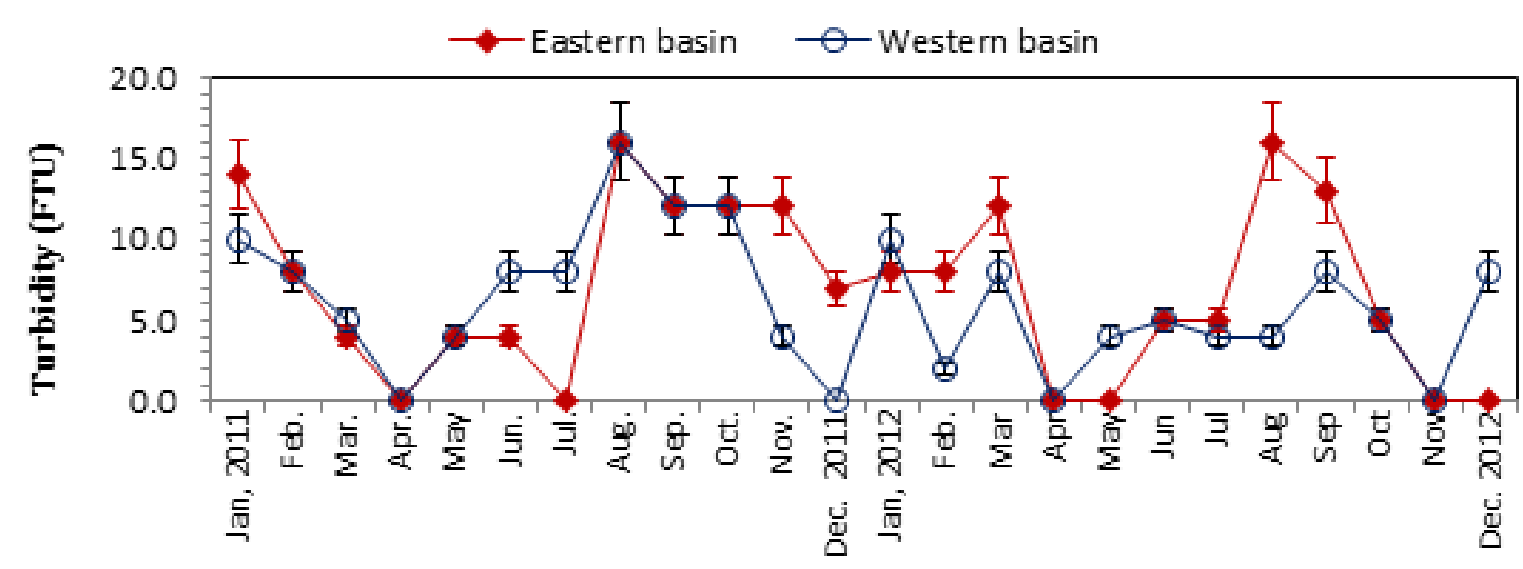

Fig. 5 Monthly variation in turbidity (FTU) in two basins of Lake Sattal during the study period (vertical bars indicates standard deviation of the mean).

Colour: The colour of the water was measured in platinum units as $\mathrm{mg} \mathrm{l}^{-1} \mathrm{Pt}$. The values ranged from 0 to $22 \mathrm{mg} \mathrm{l}^{-1} \mathrm{Pt}$ and 0 to $25 \mathrm{mg} \mathrm{l}^{-1} \mathrm{Pt}$ in eastern and western basin, respectively (Fig. $6)$. On two years mean basis, the value of colour was greater in western basin $(8.3 \pm 6.44 \mathrm{mg}$ $\left.\mathrm{I}^{-1} \mathrm{Pt}\right)$ as compared to eastern basin $(7.1 \pm 5.26$ $\mathrm{mg} \mathrm{l}^{-1} \mathrm{Pt}$ ); however, there was no significance difference between the two values. There was no any pattern in seasonality of colour values.

Alkalinity and hardness: The values of alkalinity varied from 48 to $225 \mathrm{mg} / \mathrm{l}$ and 41.0 to 128 $\mathrm{mg} / \mathrm{l}$ in eastern and western basins, respectively (Table. 2). On two years mean basis, the value of alkalinity was greater in eastern basin (87 $\pm 38.9 \mathrm{mg} / \mathrm{l})$ as compared to western basin (84 $\pm 24.7 \mathrm{mg} / \mathrm{l})$; however, there was no significant difference between the two values.

There was difference in the patterns of fluctuation of alkalinity during the two consecutive years in both basins. During 2011, the values were higher in summer season and lower during autumn and spring. In 2012, the values were greater during rainy season and lower during autumn. 


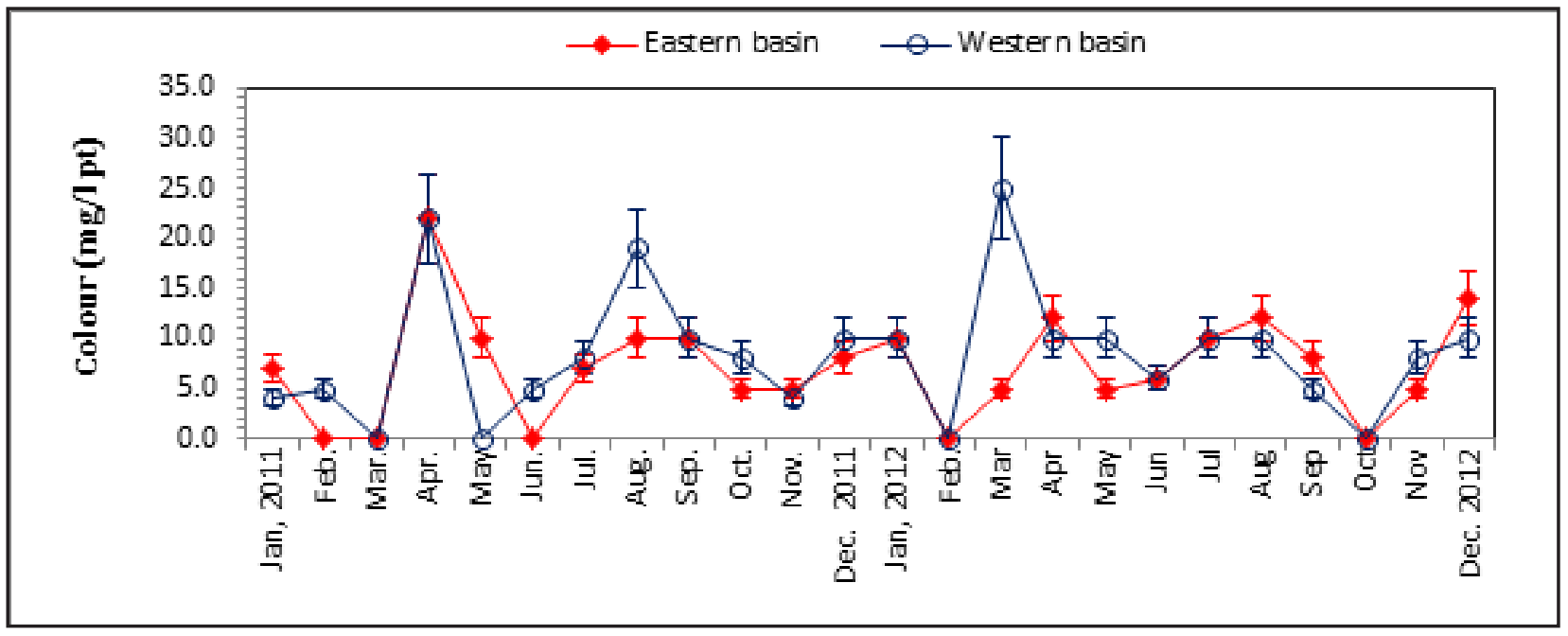

Fig. 6 Monthly variation in colour (mg/l pt) in two basins of Lake Sattal during the study period (vertical bars indicate standard deviation of the mean).

The hardness of the lake water varied from 63 to $210 \mathrm{mg} / \mathrm{l}$ and 50 to $210 \mathrm{mg} / \mathrm{l}$ in the eastern and western basins, respectively (Table. 3 ).

On two years mean basis, the value of hardness was greater in western basin (106 \pm 42.1 $\mathrm{mg} / \mathrm{l})$ as compared to eastern basin (104 \pm 33.1 $\mathrm{mg} / \mathrm{l})$; the values varied significantly from one sampling occasion to another $(p=0.07)$. No any definite pattern in seasonality was discernible. The concentration of free $\mathrm{CO}_{2}$ showed strong positive correlation $(p=0.006, r=0.547)$ with hardness.

Free carbon dioxide (CO2): The concentration of free carbon dioxide varied from 0 to 7.0 $\mathrm{mg} / \mathrm{l}$ and 0 to $8.0 \mathrm{mg} / \mathrm{l}$ in eastern and western basins, respectively (Table 4). On two years mean basis, the concentration of free $\mathrm{CO}_{2}$ was greater in western basin $(2.5 \pm 2.6 \mathrm{mg} / \mathrm{l})$ as compared to eastern basin $(2.3 \pm 2.5 \mathrm{mg} / \mathrm{l})$; however, there was no significant difference between the two values.

In general, the values of free $\mathrm{CO}_{2}$ were lower during summer season and higher during the winter season in both basins.

Hydrogen - ion concentration (pH): The lake water was always alkaline in the eastern basin but the $\mathrm{pH}$ values occasionally dropped to neutral or slightly acidic in western basin (Table. 5).
The $\mathrm{pH}$ readings ranged from 7.6 to 9.0 with biannual mean of $8.2 \pm 0.4$ in the eastern basin and 6.9 to 9.0 with a biannual mean of $8.1 \pm 0.7$ in the western basin. The values of two basins did not vary significantly. There was no any pattern in seasonality of $\mathrm{pH}$ in the lake water.

Dissolved oxygen (D.O): The dissolved oxygen in Lake Sattal was quite high. The concentration ranged from 6.4 to $11.5 \mathrm{mg} / \mathrm{l}$ and 6.2 to $11.5 \mathrm{mg} / \mathrm{l}$ in eastern and western basin, respectively (Fig. 7). On biannual mean basis, the concentration of dissolved oxygen in eastern basin was $9.0 \pm 1.5 \mathrm{mg} / \mathrm{l}$ while it was 9.1 $\pm 1.5 \mathrm{mg} / \mathrm{l}$ in western basin. Thus, there was no significant variation in dissolved oxygen concentrations of two basins. During first year, the concentration was higher in July through November and lower during January-February. During the next consecutive year, no pattern in seasonality was discernible.

At the mud-water interface, its concentrations ranged from $1 \mathrm{mg} / \mathrm{l}$ to $2.3 \mathrm{mg} / \mathrm{l}$ from January, 2011 to May, 2011. In the month of June, D.O at the mud-water interface was found to be anoxic. The presence of oxygen was again noticed in the later months.

Biochemical oxygen demand (BOD): The $B O D$ in the surface water was high. It ranged 
Table 2 Seasonal variation in alkalinity $(\mathrm{mg} / \mathrm{l})$ in two basins of Lake Sattal during the study period. SD = Standard deviation of the mean.

\begin{tabular}{|l|c|c|}
\hline Months & Eastern basin & Western basin \\
\hline January, 2011 & 60.00 & 86.00 \\
\hline February & 59.00 & 50.00 \\
\hline March & 55.00 & 55.00 \\
\hline April & 60.00 & 41.00 \\
\hline May & 85.00 & 101.00 \\
\hline June & 149.00 & 110.00 \\
\hline July & 120.00 & 94.00 \\
\hline August & 110.00 & 90.00 \\
\hline September & 98.00 & 58.00 \\
\hline October & 55.00 & 65.00 \\
\hline November & 60.00 & 60.00 \\
\hline December, 2011 & 98.00 & 120.00 \\
\hline January, 2012 & 65.00 & 112.00 \\
\hline February & 101.00 & 102.00 \\
\hline March & 80.00 & 70.00 \\
\hline April & 65.00 & 80.00 \\
\hline May & 91.00 & 95.00 \\
\hline June & 58.00 & 55.00 \\
\hline July & 725.00 & 110.00 \\
\hline August & 87.00 .00 & 128.00 \\
\hline September & & 100.00 \\
\hline October & 75.00 & 70.00 \\
\hline November & 57.00 \\
\hline December, 2012 & & \\
\hline Biannual Mean \pm SD & 25 \\
\hline
\end{tabular}

Table 3 Seasonal variation in hardness $(\mathrm{mg} / \mathrm{l})$ in two basins of Lake Sattal during the study period. SD = Standard deviation of the mean.

\begin{tabular}{|l|c|c|}
\hline Months & Eastern basin & Western basin \\
\hline January, 2011 & 110.00 & 108.00 \\
\hline February & 68.00 & 68.00 \\
\hline March & 65.00 & 50.00 \\
\hline April & 105.00 & 111.00 \\
\hline May & 132.00 & 90.00 \\
\hline June & 101.00 & 65.00 \\
\hline July & 85.00 & 84.00 \\
\hline August & 92.00 & 110.00 \\
\hline September & 75.00 & 75.00 \\
\hline October & 64.00 & 51.00 \\
\hline November & 75.00 & 90.00 \\
\hline December, 2011 & 110.00 & 110.00 \\
\hline January, 2012 & 95.00 & 185.00 \\
\hline February & 78.00 & 65.00 \\
\hline March & 110.00 & 111.00 \\
\hline April & 135.00 & 120.00 \\
\hline May & 123.00 & 98.00 \\
\hline June & 138.00 & 135.00 \\
\hline July & 123.00 & 134.00 \\
\hline August & 89.00 & 130.00 \\
\hline September & 110.00 & 98.00 \\
\hline October & 210.00 & 184.00 \\
\hline November & 600.00 \\
\hline December, 2012 & 210.00 \\
\hline Biannual mean $\mathbf{S D}$ & $106 \pm 42$ \\
\hline
\end{tabular}


Table 4 Seasonal variation concentrations of free $\mathrm{CO}_{2}$ $(\mathrm{mg} / \mathrm{l})$ in two basins of Lake Sattal during the study period $. \mathrm{SD}=$ Standard deviation of the mean .

\begin{tabular}{|l|c|c|}
\hline Months & Eastern basin & Western basin \\
\hline January, 2011 & 7.00 & 6.00 \\
\hline February & 3.00 & 2.00 \\
\hline March & 0.00 & 0.00 \\
\hline April & 0.00 & 0.00 \\
\hline May & 1.00 & 1.00 \\
\hline June & 0.00 & 1.00 \\
\hline July & 0.00 & 0.00 \\
\hline August & 3.00 & 1.00 \\
\hline September & 1.50 & 1.00 \\
\hline October & 3.00 & 2.00 \\
\hline November & 4.40 & 4.50 \\
\hline December, 2011 & 4.50 & 4.20 \\
\hline January, 2012 & 6.00 & 8.00 \\
\hline February & 0.00 & 0.00 \\
\hline March & 0.00 & 4.00 \\
\hline April & 3.00 & 0.00 \\
\hline May & 0.00 & 0.00 \\
\hline June & 0.00 & 5.00 \\
\hline July & 3.50 & 5.00 \\
\hline August & 0.00 & 0.00 \\
\hline September & 0.00 & 0.00 \\
\hline October & 5.80 & 6.00 \\
\hline November & 1.40 & 4.00 \\
\hline December, 2012 & 6.00 \\
\hline Biannual mean \pm SD & 2.6 \\
\hline
\end{tabular}

Table 5 Seasonal variation in $\mathrm{pH}$ in two basins of Lake Sattal during the study period. SD = Standard deviation of the mean.

\begin{tabular}{|l|c|c|}
\hline Months & Eastern basin & Western basin \\
\hline January, 2011 & 7.80 & 7.00 \\
\hline February & 7.80 & 8.40 \\
\hline March & 8.00 & 7.90 \\
\hline April & 8.50 & 7.00 \\
\hline May & 8.40 & 8.20 \\
\hline June & 8.20 & 8.20 \\
\hline July & 7.60 & 7.70 \\
\hline August & 7.90 & 7.40 \\
\hline September & 8.00 & 6.90 \\
\hline October & 8.60 & 7.40 \\
\hline November & 8.30 & 7.60 \\
\hline December, 2011 & 9.00 & 8.50 \\
\hline January, 2012 & 8.00 & 8.00 \\
\hline February & 8.50 & 8.50 \\
\hline March & 7.90 & 8.60 \\
\hline April & 7.80 & 8.70 \\
\hline May & 9.00 & 9.00 \\
\hline June & 8.20 & 8.70 \\
\hline July & 7.80 & 9.00 \\
\hline August & 9.00 & 8.70 \\
\hline September & 7.90 & 8.00 \\
\hline October & 7.80 & 8.80 \\
\hline November & 7.70 & 7.50 \\
\hline December, 2012 & 7.70 \\
\hline Biannual mean SD & \\
\hline
\end{tabular}


Table 6. Seasonal in concentrations of Fluoride $(\mathrm{mg} / \mathrm{l})$ in two basins of Lake Sattal during the study period. SD = Standard deviation of the mean.

\begin{tabular}{|l|c|c|}
\hline Basins seasons & Eastern basin & Western basin \\
\hline Winter, 2011 & 0.80 & 0.20 \\
\hline Spring, 2011 & 0.60 & 0.90 \\
\hline Summer, 2011 & 0.10 & 0.12 \\
\hline Monsoon, 2011 & 0.80 & 0.100 \\
\hline Autumn, 2011 & 0.31 & 0.60 \\
\hline Winter, 2012 & 1.00 & 0.54 \\
\hline Spring, 2012 & 0.75 & 0.15 \\
\hline Summer, 2012 & 0.00 & 0.21 \\
\hline Monsoon, 2012 & 0.58 & 1.00 \\
\hline Autumn, 2012 & 0.60 & 0.08 \\
\hline Biannual mean \pm SD & $\mathbf{0 . 5 5 \pm 0 . 3 1}$ & $\mathbf{0 . 3 9} \pm 0.35$ \\
\hline
\end{tabular}

from 1.4 to $8.3 \mathrm{mg} / \mathrm{l}$ in eastern basin and 1.1 to $8.0 \mathrm{mg} / \mathrm{l}$ in western basin during the whole study period (Fig. 8). On biannual mean basis, the value was higher in eastern basin $(4.8 \pm 1.9$ $\mathrm{mg} / \mathrm{l})$ as compared to the western basin (4.3 $\pm 1.9 \mathrm{mg} / \mathrm{l})$. However, the difference was not statistically significant. In general, the pattern of seasonality was almost similar in both the basins. Usually, BOD values were higher during monsoon and lower during rest of the year. BOD was negatively correlated with dissolved oxygen in the lake but the correlation was not significant $(r=-0.106, p=0.473)$.

Nitrate nitrogen (NO3-N): The concentration of $\mathrm{NO}_{3}-\mathrm{N}$ varied from 0.06 to $0.84 \mathrm{mg} / \mathrm{l}$ and 0.04 to $0.66 \mathrm{mg} / \mathrm{l}$ in eastern and western basins, respectively (Fig. 9). In eastern basin, the maximum value was found in the month of March and the minimum in the month of August during 2011.

In the consecutive year, however, the pattern was different - the maximum value was found in the month of November and minimum
Table 7. Seasonal variation in concentrations of four metallic elements in the Eastern basin of Lake Sattal during the study period. SD = Standard deviation of the mean.

\begin{tabular}{|c|c|c|c|c|}
\hline Parameters seasons & $\begin{array}{c}\mathrm{Fe} \\
(\mathrm{mg} / \mathrm{l})\end{array}$ & $\begin{array}{c}\mathrm{Mn} \\
(\mathrm{mg} / \mathrm{l})\end{array}$ & $\underset{(\mathrm{mg} / \mathrm{l})}{\mathrm{Cu}}$ & $\underset{(\mathrm{mg} / \mathrm{l})}{\mathrm{Zn}}$ \\
\hline Winter, 2011 & 0.00 & 0.003 & 0.00 & 0.17 \\
\hline Spring, 2011 & 0.00 & 0.005 & 0.00 & 0.03 \\
\hline Summer, 2011 & 0.00 & 0.002 & 0.00 & 0.075 \\
\hline Monsoon, 2011 & 0.01 & 0.002 & 0.021 & 0.12 \\
\hline Autumn, 2011 & 0.02 & 0.005 & 0.14 & 0.21 \\
\hline Winter, 2012 & 0.08 & 0.002 & 0.08 & 0.12 \\
\hline Spring, 2012 & 0.00 & 0.002 & 0.00 & 0.28 \\
\hline Summer, 2012 & 0.00 & 0.002 & 0.00 & 0.165 \\
\hline Monsoon, 2012 & 0.03 & 0.005 & 0.20 & 0.22 \\
\hline Autumn, 2012 & 0.00 & 0.003 & 0.02 & 0.23 \\
\hline Biannual Mean \pm SD & $\begin{array}{c}0.014 \\
\pm \\
0.025\end{array}$ & $\begin{array}{c}0.003 \\
\pm \\
0.001\end{array}$ & $\begin{array}{c}0.046 \\
\pm \\
0.068\end{array}$ & $\begin{array}{c}0.162 \\
\pm \\
0.073\end{array}$ \\
\hline
\end{tabular}

occurred in December. In the western basin, the maximum concentration during 2011 was in March and minimum was found in February. In 2012, the maximum concentration was noticed in August while the minimum was recorded in May. The biannual mean concentrations in eastern and western basins were $0.32 \pm 20$ $\mathrm{mg} / \mathrm{l}$ and $0.33 \pm 16 \mathrm{mg} / \mathrm{l}$, respectively.

Ammoniacal-nitrogen (NH4-N): The concentrations of ammoniacal nitrogen in Lake Sattal varied significantly from one sampling occasion to another $(p=0.033)$.

In eastern basin, it varied from 0 to $0.65 \mathrm{mg} / \mathrm{l}$ while in western basin it ranged between 0 and $0.56 \mathrm{mg} / \mathrm{l}$ during the entire study period (Fig. 10). On biannual mean basis, the concentrations of $\mathrm{NH}_{4}-\mathrm{N}$ were $0.20 \pm 0.21 \mathrm{mg} / \mathrm{l}$ and 0.18 $\pm 0.18 \mathrm{mg} / \mathrm{l}$ in eastern and western basins, respectively. In general, the concentrations of ammoniacal nitrogen in both the basins were 
Table 8 Seasonal variation in concentrations of four metallic elements in western basin of Lake Sattal during the study period. SD = Standard deviation of the mean.

\begin{tabular}{|l|c|c|c|c|}
\hline $\begin{array}{l}\text { Parameters } \\
\text { seasons }\end{array}$ & $\begin{array}{c}\mathrm{Fe} \\
(\mathrm{mg} / \mathrm{l})\end{array}$ & $\begin{array}{c}\mathrm{Mn} \\
(\mathrm{mg} / \mathrm{l})\end{array}$ & $\begin{array}{c}\mathrm{Cu} \\
(\mathrm{mg} / \mathrm{l})\end{array}$ & $\begin{array}{c}\mathrm{Zn} \\
(\mathrm{mg} / \mathrm{l})\end{array}$ \\
\hline Winter, 2011 & 0.07 & 0.008 & 0.033 & 0.13 \\
\hline Spring, 2011 & 0.00 & 0.03 & 0.08 & 0.32 \\
\hline Summer, 2011 & 0.03 & 0.003 & 0.00 & 0.08 \\
\hline Monsoon, 2011 & 0.00 & 0.002 & 0.025 & 0.184 \\
\hline Autumn, 2011 & 0.06 & 0.003 & 0.125 & 0.13 \\
\hline Winter, 2012 & 0.08 & 0.002 & 0.00 & 0.09 \\
\hline Spring, 2012 & 0.02 & 0.003 & 0.001 & 0.27 \\
\hline Summer, 2012 & 0.02 & 0.003 & 0.001 & 0.10 \\
\hline Monsoon, 2012 & 0.02 & 0.002 & 0.014 & 0.10 \\
\hline Autumn, 2012 & 0.00 & $\mathbf{0 . 0 3}$ & 0.08 & 0.21 \\
\hline $\begin{array}{l}\text { Biannual Mean } \\
\mathbf{\pm} \text { SD }\end{array}$ & $\begin{array}{c}\mathbf{0 . 0 3 0} \\
\mathbf{0 . 0 3 0}\end{array}$ & $\begin{array}{c}\mathbf{0 . 0 0 9} \mathbf{0 . 0 1 1} \\
\mathbf{0 . 0 3 6}\end{array}$ & $\mathbf{0 . 0 4 4}$ & $\mathbf{0 . 1 6 1 \pm}$ \\
\hline
\end{tabular}

higher during August to November and lower during January to July.

Nitrite-nitrogen (NO2-N): The concentration of nitrite nitrogen was very low in the lake. It varied from 0 to $0.08 \mathrm{mg} / \mathrm{l}$ and 0 to $0.07 \mathrm{mg} / \mathrm{l}$ in eastern and western basins, respectively during the two years study period (Fig.11). On biannual mean basis, the concentration of nitrite nitrogen was higher in western basin $(0.03 \pm 0.02 \mathrm{mg} / \mathrm{l})$ than that of eastern basin $(0.02 \pm 0.02 \mathrm{mg} / \mathrm{l})$.

Thus, the water samples of two basins were not different with regard to nitrite nitrogen. In general, the concentrations of nitrite nitrogen in both the basins were higher during rainy and winter season and lower in rest of the year.

Phosphate-phosphorous (PO4-P): The concentration of phosphate phosphorous ranged between 0.02 and $0.14 \mathrm{mg} / \mathrm{l}$ in eastern basin while it varied from 0.01 to $0.16 \mathrm{mg} / \mathrm{l}$ in western basin (Fig.12). There was no any definite pattern in seasonal variation of phosphorous concentration. On biannual mean basis, the concentration of phosphate phosphorous was $0.06 \pm 0.03 \mathrm{mg} / \mathrm{l}$ in eastern basin and $0.05 \pm 0.04 \mathrm{mg} / \mathrm{l}$ in western basin.

Fluoride: The concentration of fluoride was analysed five times in a year. The concentration varied from 0 to $1.000 \mathrm{mg} / \mathrm{l}$ with biannual mean of $0.55 \pm 0.31 \mathrm{mg} / \mathrm{l}$ in eastern basin and $0.080 \mathrm{mg} / \mathrm{l}$ to $1.000 \mathrm{mg} / \mathrm{l}$ with a mean of $0.39 \pm$ $0.35 \mathrm{mg} / \mathrm{l}$ in western basin (Table 6).

Metallic contents: Table $7 \& 8$ contains the data on the concentration of Iron (Fe), Manganese $(\mathrm{Mn})$, Copper $(\mathrm{Cu})$ and Zinc $(\mathrm{Zn})$ in surface water of two basins in the lake. The biannual mean concentrations of iron, manganese, copper and zinc in eastern basin were: $0.014 \pm 0.025 \mathrm{mg} / \mathrm{l}, 0.003 \pm 0.001 \mathrm{mg} / \mathrm{l}, 0.046$ $\pm 0.068 \mathrm{mg} / \mathrm{l}$ and $0.162 \pm 0.073 \mathrm{mg} / \mathrm{l}$, respectively.

Similar mean concentrations for iron, manganese, copper and zinc in western basin were: $0.030 \pm 0.030 \mathrm{mg} / \mathrm{l}, 0.009 \pm 0.011 \mathrm{mg} / \mathrm{l}, 0.036 \pm$ $0.044 \mathrm{mg} / \mathrm{l}$ and $0.161 \pm 0.082 \mathrm{mg} / \mathrm{l}$, respectively.

Thus, the concentrations of iron and manganese were higher in western basin as compared to eastern basin, while the concentration of copper was higher in eastern basin as compared to western basin. The concentration of zinc was equal in both basins. Significant variation $(p=0.004)$ in seasonality of manganese concentration was observed in both basins of the lake.

Solar radiation is the main source of heat to lakes. Most of the sun heat is directly absorbed by the water. Some absorption is also made by the sediment (Wetzel, 2001). Heat is an important constituent of the water body which affects the metabolic activities of the aquatic organisms. Mainly it affects the breeding activities of organisms. The heat absorbing capacity of the lake also affects the microclimate of the area in which the lakes are situated. The high temperature of water during summer in Lake Sattal and 


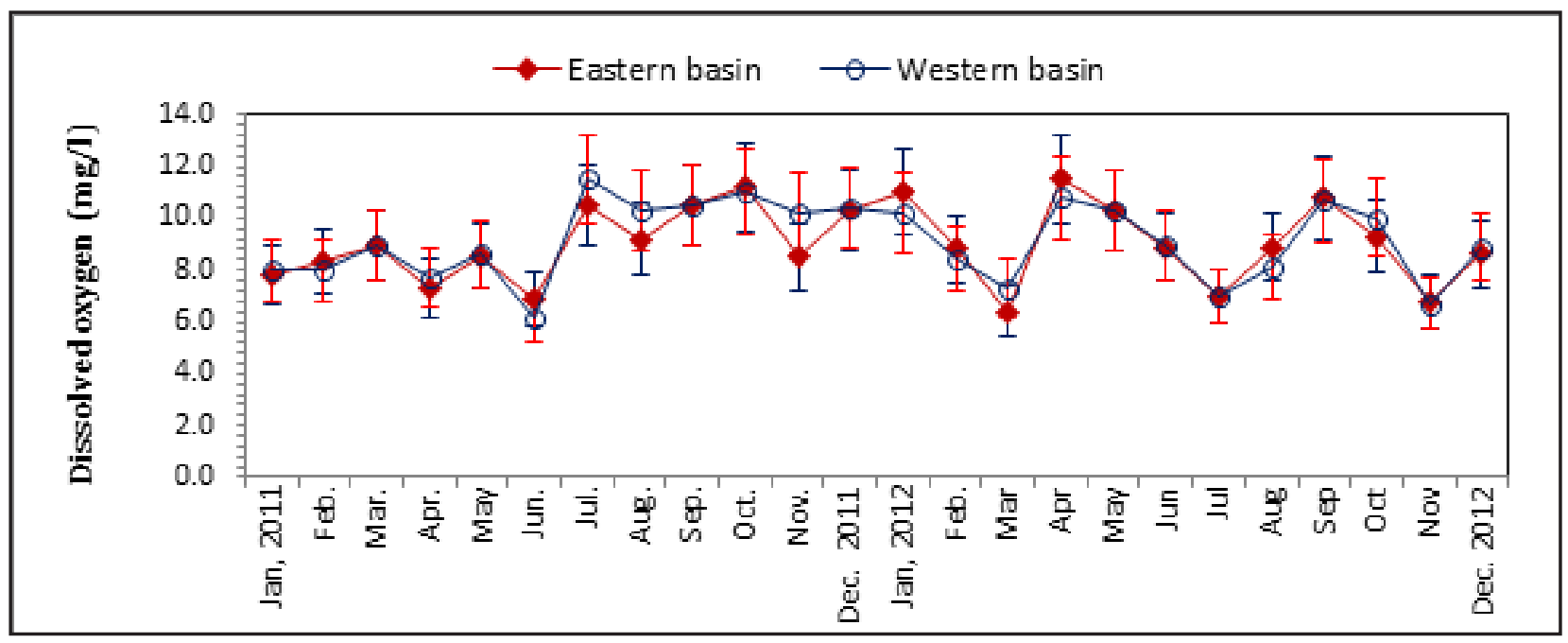

Fig. 7 Seasonal variation in concentration of dissolved oxygen $(\mathrm{mg} / \mathrm{l})$ in two basins of Lake Sattal during the study period (vertical bars indicates standard deviation of the mean).

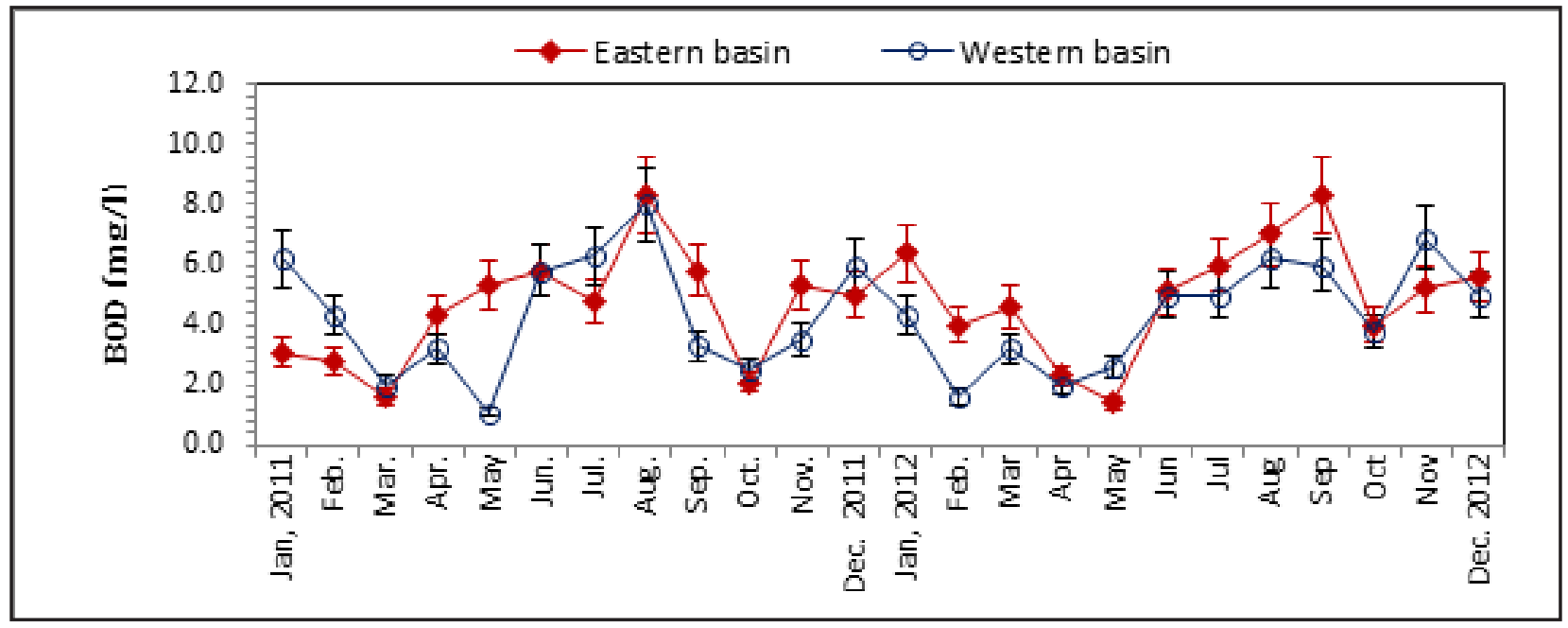

Fig. 8 Seasonal variation in Bio-chemical Oxygen Demand (mg/l) in two basins of Lake Sattal during the study period (vertical bars indicates standard deviation of the mean).

low temperature during winters suggested that the lake stored sufficient amount of heat during summer and released significant amount of heat during winter. Hutchinson (1957) has classified the world lake into different categories depending on the time of thermal stratification and water circulation. On this basis, Lake Sattal can be classified as warm monomictic lake as the lake experienced circulation during winters and remained thermally stratified during rest of the year. Nevertheless, the thermo- cline was poorly defined. In both the basins, the periods of thermal stratification and circulation were same as both are connected with a broad channel.

Water transparency is an important feature of water quality and has ecological implications that cannot be ignored. Transparency of water is generally governed by falling light intensity, concentrations of dissolved substances, suspended solids, biomass and particulate matters, etc. About three decades ago when the lake was 


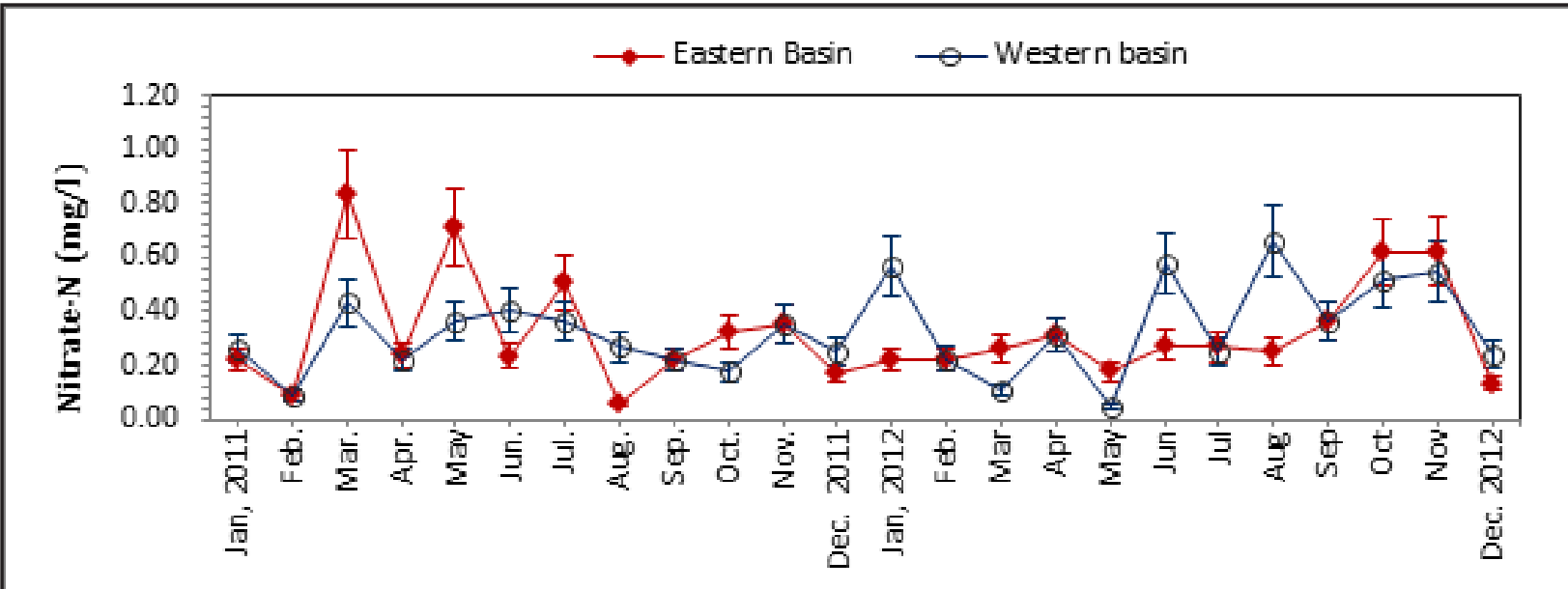

Fig. 9 Seasonal variation in concentrations of nitrate- $\mathrm{N}(\mathrm{mg} / \mathrm{l})$ in two basins of Lake Sattal during the study period (vertical bars indicate standard deviation of the mean).

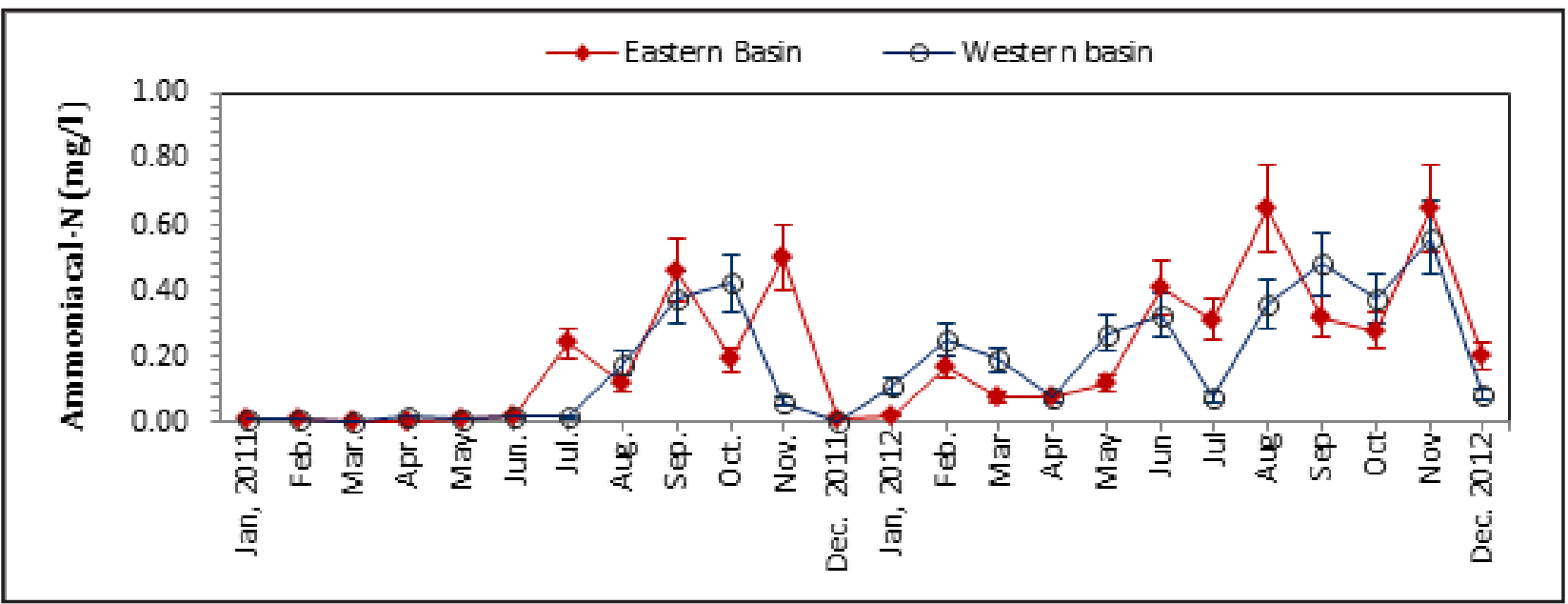

Fig. 10 Seasonal variation in concentrations of ammoniacal-N (mg/l) in two basins of Lake Sattal during the study period (vertical bars indicate standard deviation of the mean).

studied for the first time (Pant and Joshi 1987), the water transparency was found to be 1.0 to $3.0 \mathrm{~m}$. In the present investigation, the water transparency of the lake varied from 1.1 to 3.2 $\mathrm{m}$. Thus, the transparency has not changed after a gap of three decades. The annual mean transparency of Lake Sattal $(2.3 \mathrm{~m})$ is higher than other lakes of Kumaun (Gupta, personal communication). This could be attributed to low amounts of dissolved substances, particulates and suspended solids and biomass in water.
Besides, the higher transparency of Lake Sattal may also be due to low floodwater and surface runoff. Turbidity is a measure of the light scattering properties of water and describes how suspended particles or colloidal matter affect water transparency by obstructing light transmission. Inorganic or organic matter or a combination of the two is generally responsible for turbidity. Turbidity around 50 FTU is referred to as 'cloudy' and 100-500 FTU is designated as 'muddy' water. Prolong exposures at 25 FTU turbidity 


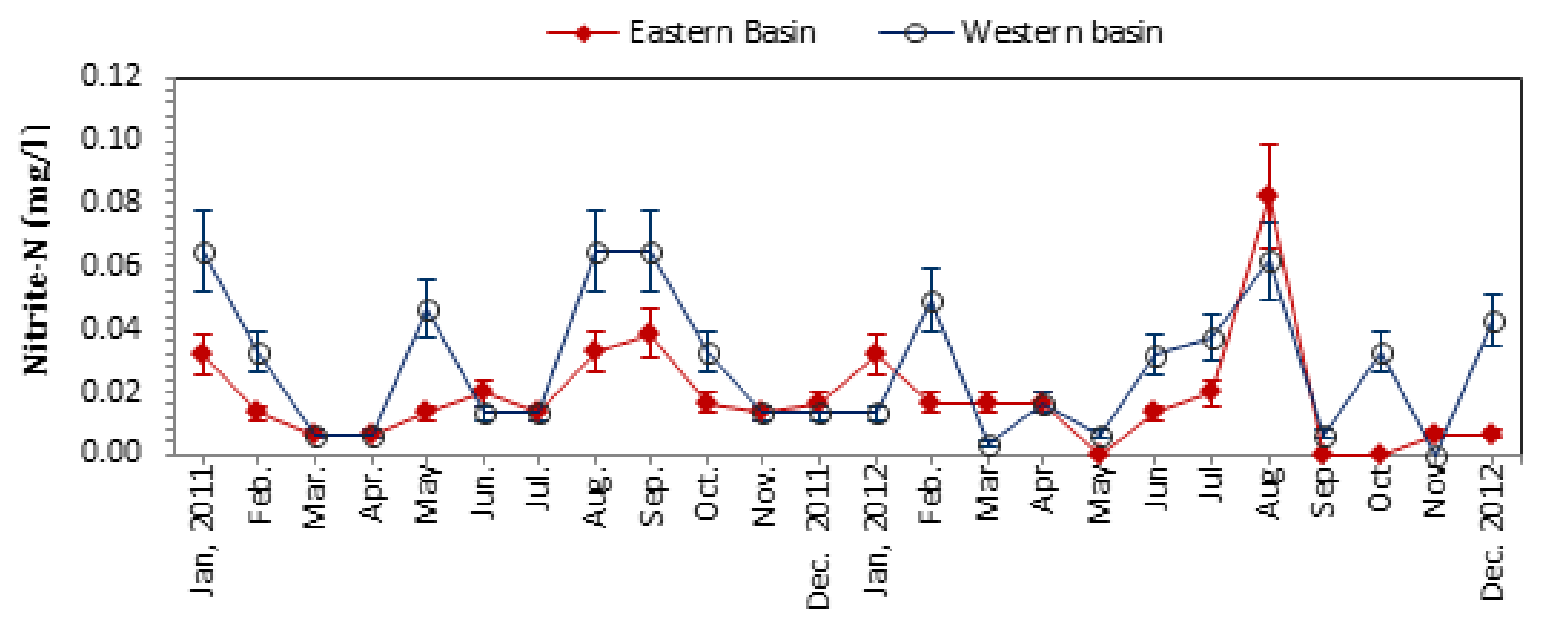

Fig. 11 Seasonal variation in concentrations of nitrite- $\mathrm{N}(\mathrm{mg} / \mathrm{l})$ in two basins of Lake Sattal during the study period (vertical bars indicate standard deviation of the mean).

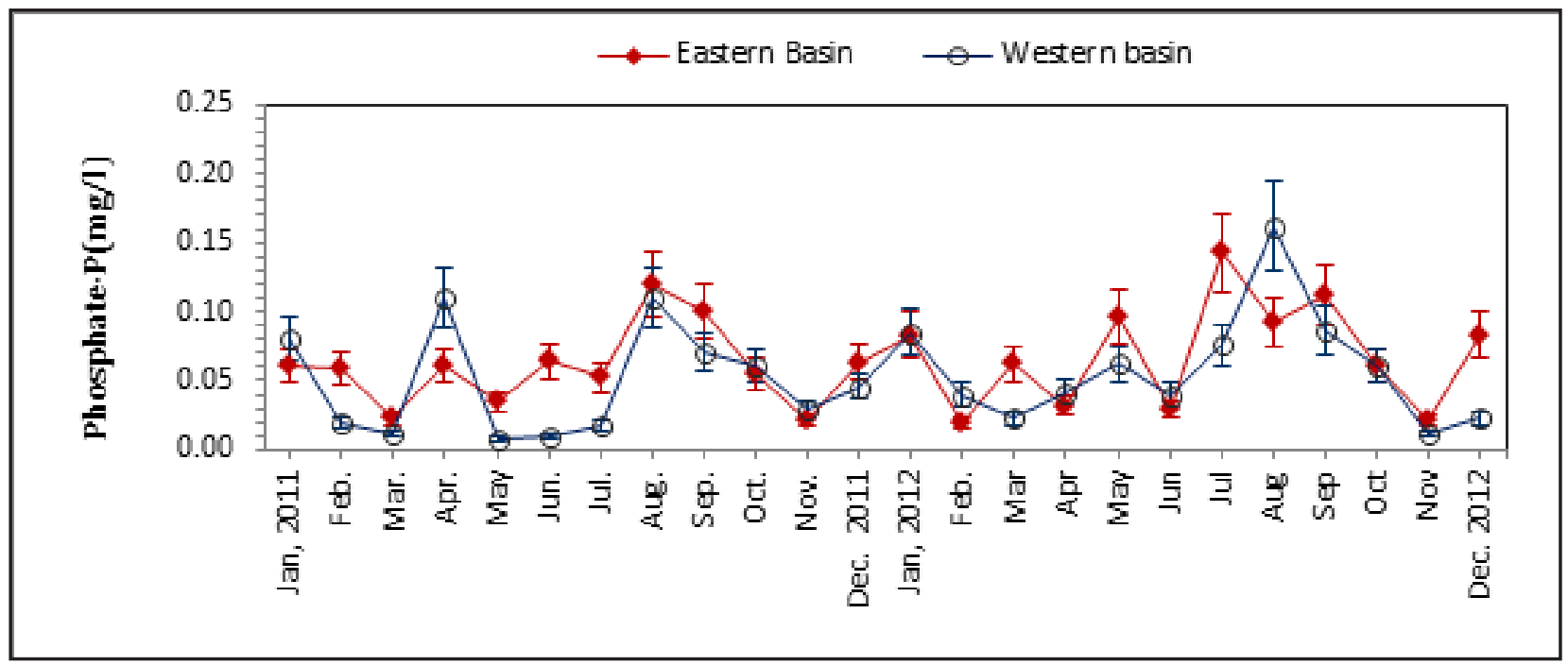

Fig. 12 Seasonal variation in concentrations of phosphate-P $(\mathrm{mg} / \mathrm{l})$ in two basins of Lake Sattal during the study period (vertical bars indicate standard deviation of the mean).

may cause stress to some fishes (Sedaghat and Hoseini 2012). Lake Sattal can be categorized into clear water in terms of turbidity as the biannual mean values of turbidity in the lake were: 6.9 FTU in eastern basin and 6.0 FTU in western basin.

The colour of water is determined mainly by colour of particulate matter and colour of plank- ton present in the water. Dark or blue-green colour is imparted by blue-green algae, yellowbrown colour is given by diatoms and red and purple colours are provided by zooplankton such as Daphnia or copepods (WHO/UNEP $1996 \mathrm{~b}$ ). Colour of the natural waters can range from $<5 \mathrm{mg} / \mathrm{l} \mathrm{pt} \mathrm{in} \mathrm{very} \mathrm{clear} \mathrm{waters} \mathrm{to} 300 \mathrm{mg} / \mathrm{l}$ pt in dark peaty waters (WHO/UNEP 1996 a). 
Some data are available on the colour values of Kumaun lakes. Lake Nainital had the colour value ranging from 18 to $80 \mathrm{mg} / \mathrm{l}$ pt (Nagdali 2002), while Naukuchiyatal lake had the values ranging from 5 to $50 \mathrm{mg} / \mathrm{l} \mathrm{pt}$ with annual value of $27 \mathrm{mg} / \mathrm{l}$ pt (Bhagat 2002). As compared to these lakes, Lake Sattal had quite low colour values (biannual mean for eastern basin $=7.1 \mathrm{mg} / \mathrm{l} \mathrm{pt}$ and for western basin $=8.3 \mathrm{mg} / \mathrm{l}$ pt). It was perhaps due to low suspended and dissolved impurities as compared to the other lakes of Kumaun. According to WHO/UNEP (1996 a) classification, Lake Sattal can be classified as clear water body. The exceptional high values of colour in the month of April could be due to high growth of plankton as this month usually received high light intensity and therefore high rate of photosynthesis.

$\mathrm{pH}$ of the water is mainly associated with the concentration of carbon dioxide, carbonate ions as well as other natural compounds. The carbon-dioxide in turn is related with the photosynthetic activity of organisms (Hutchinson 1957). At a given temperature, $\mathrm{pH}$ specifies the degree of acidity and alkalinity of the water body and is controlled by the dissolved chemicals and biochemical processes in the water. The present water body remained alkaline almost throughout the study period. In the present study, free $\mathrm{CO}_{2}$ showed negative correlation with $\mathrm{pH}$ which is a universal phenomenon. The alkaline nature of the water body throughout the study period indicated the productive nature of the lake (Wetzel 1975).

Phillipose (1960) has classified lakes into three categories on the basis of alkalinity values. According to him, low nutrient level lakes have alkalinity values ranging from 4 to $50 \mathrm{mg} / \mathrm{l}$ and are classified as low productive lakes. The lakes having alkalinity values of 50 to $100 \mathrm{mg} / \mathrm{l}$ are signified as moderately productive, whereas the lakes having alkalinity values ranging from 100 to $600 \mathrm{mg} / \mathrm{l}$ are assigned to highly productive category. The present lake with its biannual mean alkalinity values ranging from 83.5 to $87.2 \mathrm{mg} / \mathrm{l}$ (in western and eastern basins, respectively) can be called as moder- ately productive lake.

The values of alkalinity were positively correlated $(P<0.01)$ with the rainfall data. This implied that surface run-off from the catchment contained substances which contribute to alkalinity. Bureau of Indian Standard (1994) has set a criterion of alkalinity for fisheries. According to BIS and US EPA, the alkalinity values in a water body ranging from $20 \mathrm{mg} / \mathrm{l}$ to $300 \mathrm{mg} / \mathrm{l}$ is believed to be suitable for fisheries and aquatic life. If this criterion is followed, Lake Sattal can be considered as a good water body for fisheries development.

The hardness of natural waters depends mainly on the presence of dissolved calcium and magnesium salts which are linked with bicarbonates, sulphites, carbonates, sulphates and other ions. It may vary over wide ranges. The biannual mean value of hardness of Lake Sattal (104-106 mg/l in two basins) is comparable with the mean value of a nearby lake, Lake Naukuchiyatal in which $98 \mathrm{mg} / \mathrm{l}$ of hardness has been reported by Bhagat (2002). The effects of hardness on freshwater fishes and other aquatic life appear to be related to the ions causing the hardness rather than hardness itself (US E.P.A. 1976). Many workers (e.g. Barett, 1957) have noticed that hard water lakes are generally more productive than soft water lakes. Desirable concentration of total hardness for fish culture generally ranges from 20 to $300 \mathrm{mg} / \mathrm{l}$ (Boyd and Walley 1975). The biannual mean values of hardness of Lake Sattal varied from 104 to $106 \mathrm{mg} / \mathrm{l}$ for two basins which indicates the suitability of the lake for fish production. With regard to drinking water quality, hardness below $300 \mathrm{mg} / \mathrm{l}$ is considered portable; beyond this limit the consumption of the water causes gastrointestinal irritation (ICMR 1975). In this respect also, the water of Lake Sattal is suitable for potable water supply.

Dissolved oxygen of the water is used in respiration by aquatic organisms. The main source of oxygen in the water is the photosynthesis performed by autotrophs, besides being diffused from the atmosphere into the water. It is an important water quality parameter that reflects 
the physical and biological processes prevailing in the water. It is traditionally concerned by most of the limnologist because it may cause fish kills at low concentrations. Fish and other aquatic life require specific levels of dissolved oxygen to survive. Depletion of DO frequently occurs in most water bodies due to seasonal algal blooms. The amount of oxygen dissolved in the water changes with change in temperature. It is known that a concentration of more than $5 \mathrm{mg} / \mathrm{l}$ dissolved oxygen is required for the survival and good health of fishes (US EPA, 1976). For the good health of cold water aquatic biota, a range of $6.5-9.5 \mathrm{mg} / \mathrm{l} \mathrm{DO}$ is suggested by WHO/ UNEP (1997). In the present lake the values of DO ranged from 6.2 to $11.5 \mathrm{mg} / \mathrm{l}$ with biannual mean of $9.0 \mathrm{mg} / \mathrm{l}$. This indicated that the DO concentration in the lake was optimum for the proper health of the fishes and other aquatic biota. In the present water body, no algal bloom occurred during the study period.

The biochemical oxygen demand of a water body indicates the level of organic pollution. According to ICMR (1963), a level of more than $6 \mathrm{mg} / \mathrm{l}$ of BOD in a natural water body is indicative of water pollution. In the present water body, the biannual means value of BOD were 4.3 and $4.8 \mathrm{mg} / \mathrm{l}$ in eastern and western basins, respectively which suggested that the water body was not polluted. The concentration of dissolved oxygen and BOD showed inverse relationship $(r=-0.106)$ in the present investigation which was usual.

Carbon dioxide is mainly formed by the respiratory activities by biota and is used in photosynthesis. The concentration of free $\mathrm{CO}_{2}$ in the present investigation was found to be very low, sometimes absent during the spring and summers when algal activities usually remain high. This indicated high photosynthetic utilisation rate of carbon during these periods. During these periods, the concentration of DO was high as it evolved as a result of photosynthesis.

Much attention has been paid now-a-days on the nutrients level of water, especially nitrogen and phosphorous. Nutrients economy in the lakes is primarily controlled by the quality of surface runoff water and phytoplankton communities of the lake (Dillon and Rigler 1974; Tilman et al.1982; Peterjohn and Correll 1984; Woltemade 2000). Increase in N and $P$ input in aquatic ecosystems encourage the growth of algae. These nutrients strongly influence and limit the growth of phytoplankton and other aquatic plants in water. Due to this, serious degradation of aquatic ecosystem through algal bloom, high BOD, low dissolved oxygen, fish death and other effects have been observed which lead to loss of biodiversity (Vollenweider 1968; Schindler 1987; Smith et al. 1999; Nagdali 2002; Bhagat 2002).

In the present water body, the $\mathrm{NO}_{3}-\mathrm{N}$ concentration varied from 0.04 to $0.84 \mathrm{mg} / \mathrm{l}$ with a biannual mean of $0.33 \mathrm{mg} / \mathrm{l}$ in two basins. These values are greater than the values (0.25 $\mathrm{mg} / \mathrm{l}$ ) reported by Joshi (1983) in the same water body about three decades back. This indicated that the level of eutrophication increased with the passage of time. Algal growth is generally stimulated and eutrophication is likely to occur in lakes where the concentration of $\mathrm{NO}_{3}-\mathrm{N}$ reaches more than 0.02 $\mathrm{mg} / \mathrm{l}$ (WHO/UNEP $1996 \mathrm{a}$ ). Unpolluted natural waters usually contain only minute amounts of nitrate. Under natural condition, concentrations seldom exceed $0.1 \mathrm{mg} / \mathrm{l}$. Since, the concentration of $\mathrm{NO}_{3}-\mathrm{N}$ in Sattal lake is more than the limit set by WHO/UNEP (1996 a), it can be expected that eutrophication may further increase in this lake in near future.

Nitrite is an intermediate stage in nitrogen cycle formed from nitrate or ammonium ions. It is a product of nitrification process, governed by biochemical processes and microorganisms in water bodies. High level of nitrite is toxic to fish because it makes the blood incapable of oxygen transport. Fishes like salmonids are more prone to toxicity of nitrite than others (Russo and Thurson 1977). In Lake Sattal the biannual mean concentrations of $\mathrm{NO}_{2}-\mathrm{N}$ were $0.02 \pm 0.02 \mathrm{mg} / \mathrm{l}$ in eastern basin and $0.03 \pm$ $0.02 \mathrm{mg} / \mathrm{l}$ in western basin. These data are comparable with the values of nearby lakes: 
Lake Nainital and Lake Naukuchiyatal. In Lake Nainital, the average concentration of $\mathrm{NO}_{2}-\mathrm{N}$ was reported as $0.064 \mathrm{mg} / \mathrm{l}$ during pre-aeration and $0.146 \mathrm{mg} / \mathrm{l}$ during aeration period (Gupta and Gupta 2012); in Lake Naukuchiyatal, the average concentration has been reported as $0.04 \mathrm{mg} / \mathrm{l}$ by Bhagat (2002). Thus, the values in Lake Sattal were quite low as compared to these two lakes of Kumaun. Nitrate and nitrite are interrelated with each other, as former is reduced to latter by microbes, and again latter is quickly converted back to former as it is less stable. Similar to the present observation, higher concentration of nitrate has been observed as compared to nitrite in most of the water bodies.

The concentration of $\mathrm{NH}_{4}-\mathrm{N}$ in the present water body can be compared with that of other water bodies of Kumaun. For example, in Nainital Lake its concentration has been reported as 0.12 to $0.27 \mathrm{mg} / \mathrm{l}$ (Nagdali 2002), while in Lake Naukuchiyatal the concentration has been found to be $0.20 \mathrm{mg} / \mathrm{l}$ (Bhagat 2002). Gupta and Gupta (2012) have reported the concentration of $\mathrm{NH}_{4}-\mathrm{N}$ as $0.58 \mathrm{mg} / \mathrm{l}$ during pre-aeration and $1.31 \mathrm{mg} / \mathrm{l}$ during aeration period of the Nainital lake. U.S. EPA (1976) has set a tolerance limit of $\mathrm{NH}_{4}-\mathrm{N}$ for humans and fish fauna. Accordingly, a concentration of greater than $0.5 \mathrm{mg} / \mathrm{l}$ and $2.5 \mathrm{mg} / \mathrm{l}$ are harmful to humans and fishes, respectively. In this context, Lake Sattal could be considered as safe for fishes and other aquatic organisms.

Phosphorous is an important water quality parameter and plays a key role in biological productivity in aquatic system. Its concentration is related with phytoplankton and macrophytes growth. It also provides information on the trophic status of lakes (Edmondson 1961; Vollenweider 1968). Indirect effects of phosphorus can also be seen on the other biotic component of the ecosystem. Very low concentration of phosphorous can depress the phytoplankton growth and can eliminate the blooms (Dillon and Rigler 1974; Jones and Bachmann 1976; Smith 1982; Canfield 1983). Phosphorous may be regenerated from the sediment into the water column after the death and decay of plankton. A concentration of 0.01 $\mathrm{mg} / \mathrm{l}$ of phosphorous may stimulate the blue green algae to bloom (U.S. EPA 1976).

In the present water body, the biannual mean concentration of phosphate-phosphorous was $0.06 \pm 0.03 \mathrm{mg} / \mathrm{l}$ in eastern basin and 0.05 $\pm 0.04 \mathrm{mg} / \mathrm{l}$ in western basin which were six times greater than the value needed to stimulate the growth of blue green algae. The concentration of phosphorous in Sattal lake can be compared with those of other lakes of Kumaun. In Lake Naukuchiyatal, the biannual mean concentration of $\mathrm{PO}_{4}-\mathrm{P}$ has been reported as 0.04 $\mathrm{mg} / \mathrm{l}$ (Bhagat, 2002) and in Lake Nainital, it has been found to be $0.11 \mathrm{mg} / \mathrm{l}$ during pre-aeration and $0.34 \mathrm{mg} / \mathrm{l}$ during aeration period (Gupta and Gupta 2012). Thus the concentration of phosphate phosphorous in the present water body was slightly greater than Lake Naukuchiyatal and markedly lower than Lake Nainital. The difference in $\mathrm{PO}_{4}-\mathrm{P}$ concentration among various lakes may be attributed to morphometric features of the lakes, besides the amount of phosphorous being externally supplied from the catchment (Edmondson 1961; Tailing 1971; Ahl 1980 and Smith 1986) and internally by the anoxic sediment.

In Lake Sattal, the peak values of $\mathrm{PO}_{4}-\mathrm{P}$ were observed during the monsoon months. Meteorological events such as the monsoon indirectly influence the temporal variation in the phosphorous concentration (Barnes 2002). A significant negative correlation $(r=-0.37, p<$ 0.05 ) between transparency and phosphorous concentration in the lake showed that high concentration of $\mathrm{PO}_{4}-\mathrm{P}$ could result in low transparency due to increased growth of phytoplankton caused by phosphorous. The mean concentration of $\mathrm{PO}_{4}-\mathrm{P}$ showed no significant differences between the two basins. This could be due to small size of the lake and also because of the regular mixing of water of two basins. About three decades ago, the concentration of $\mathrm{PO}_{4}-\mathrm{P}$ in Lake Sattal was reported as 0.001 $\mathrm{mg} / \mathrm{l}$ (Joshi 1983). The biannual mean concentration of $\mathrm{PO}_{4}-\mathrm{P}$ during the present study has 
been found to be $0.06 \mathrm{mg} / \mathrm{l}$. This is sixty times greater concentration than that of previously reported value. This marked increase in concentration in last three decades could be the results of changes in land use patterns, extensive land clearance, agriculture and suburban development in the catchment, etc. In addition, domestic sewages including waste water from households, detergents, human and cattle excreta, etc. might also increase the concentration of $\mathrm{PO}_{4}-\mathrm{P}$ in the lake.

Although low concentrations of metallic contents are essential for the aquatic life, their high concentrations beyond a certain limit may adversely affect the biota. The metallic elements may go into the sediments from the water or diffuse from the sediment to the overlying water depending on the oxic and anoxic situations at the mud-water interface. Iron and manganese are vital for biological productivity and to nutrient cycling particularly of phosphate. The mean biannual concentrations of iron, manganese, copper and zinc in the present water body were: $0.014 \pm 0.025 \mathrm{mg} / \mathrm{l}, 0.003 \pm 0.001 \mathrm{mg} / \mathrm{l}$, $0.046 \pm 0.071 \mathrm{mg} / \mathrm{l}$ and $0.162 \pm 0.077 \mathrm{mg} / \mathrm{l}$, respectively. These data can be compared with those of Lakes Naukuchiyatal and Nainital. In Lake Naukuchiyatal, the annual mean concentrations of iron, manganese, copper and zinc have been reported to be $0.10 \mathrm{mg} / \mathrm{l}, 0.05 \mathrm{mg} / \mathrm{l}$, $0.24 \mathrm{mg} / \mathrm{l}$ and $0.11 \mathrm{mg} / \mathrm{l}$, respectively, by Bhagat (2002). In Lake Nainital, The concentrations of these metallic elements have been found to be $0.011 \mathrm{mg} / \mathrm{l}, 0.007 \mathrm{mg} / \mathrm{l}, 0.024$ and 0.152 $\mathrm{mg} / \mathrm{l}$, respectively by Gupta et al. (2010). Differences in the concentration of these elements from one lake to another may be related with several factors for example differences in the local geological condition in the catchment, oxic or anoxic conditions at the mud-water-interface and many other factors. The concentrations of some elements in the water bodies are also related with the portability of the water. For example, the desirable and the permissible limit of iron are 0.3 and $1.0 \mathrm{mg} / \mathrm{l}$, of copper 0.05 and $1.5 \mathrm{mg} / \mathrm{l}$ while that of manganese are 0.1 and $0.3 \mathrm{mg} / \mathrm{l}$. In Lake Sattal, the values of these ele- ments were lower than the limit set for drinking water quality by BIS (1991). Concentrations of these elements are also related with the freshwater fish culture program. For example, the tolerance limit of freshwater fishes for iron is reported to be $2 \mathrm{mg} / \mathrm{l}$, for copper it is $0.05 \mathrm{mg} / \mathrm{l}$ and for zinc it is $0.5 \mathrm{mg} / \mathrm{l}$. In Lake Sattal the concentration of these elements were less than the tolerance limits for fishes. Therefore, the water body can be regarded as suitable for fish culture program.

Fluoride is the chemical constituent of great health concern particularly for the development of teeth and bone. Nevertheless, its high intake adversely affects the skeletal tissues (bones and teeth). This process is called fluorosis. Data on fluoride concentration of some nearby lakes are available for comparison. In Lake Naukuchiyatal, its annual mean concentration has been reported as $0.15 \mathrm{mg} / \mathrm{l}$ (Bhagat 2002). In Lake Nainital, its annual concentration has been found to be $0.96 \mathrm{mg} / \mathrm{l}$ (Gupta et al. 2010). Thus, the annual mean concentration of Lake Sattal $(0.39 \mathrm{mg} / \mathrm{l})$ is considerably lower as compared to that of Nainital and higher than that of Naukuchiyatal. The recommended limit of fluoride in drinking water is $1.5 \mathrm{mg} / \mathrm{l}$ as per W $\mathrm{H} \mathrm{O}$ and 1 to $1.5 \mathrm{mg} / \mathrm{l}$ as per Bureau of Indian Standard (BIS 1994). In the present water body, the annual mean concentration of fluoride was within the prescribed limit of above mentioned two agencies.

The data on the concentration of several parameters of water quality were examined and compared with the Bureau of Indian Standard (BIS 1991, 1992, 1994) for human consumption and other uses and quality tolerances for fresh water fish culture. As per norms of BIS and Central Water Commission for drinking water, the lake water was also suitable for drinking after proper treatment and disinfection. The increased concentrations of phosphorous and nitrogen in water in the lake signify that the lake has become eutrophic. The periodic anoxia at mud-waterinterface strongly suggests that the process of eutrophication has recently started but with a slow pace. The most important and detrimen- 
tal process of periodic anoxia may show its long term effect in near future. At present, the lake can be used for fish production by artificial culture as the quality of water is suitable. To check the anoxia at mud-water interface, urgent remedial measures should be undertaken as the lake is not only a tourist attraction spot but it can be used for drinking water supply to the local population and tourists. Some remedial measures to check further eutrophication may include checking soil erosion in the catchment, ban in bathing and using detergents, ban on cleaning utensils in the lake, etc.

\section{Acknowledgements}

The authors are thankful to Mr. Mukesh Joshi for valuable assistance during the sampling activities.

\section{References}

A.P.H.A. (2005) Standard Methods for Examination of Water and Waste Water. American Public Health Association, New York.

Ahl, T. (1980) Eutrophication in relation to the load of pollution. Prog. Water Technol. 12, 49-61.

Barrett. P.H. (1957) Potassium concentration in fertilized trout lakes. Limnol. Oceanogr. 2, 287-294.

Bhagat, P. (2002) Limnological investigation on Lake Naukuchiyatal. Ph.D. thesis, Kumaon University, Nainital.

Bhagat, P. and Gupta, P.K. (2005) Trophic status of a high altitude Himalayan lake, Lake Naukuchiyatal, as reflected by physico-chemical parameters. pp. 373-385. In: Plants Responses to Environmental Stress (Ed. Tripathi, R. D. et al). IBD Co. Publishers, Lucknow.

Boyd, C.E and Walley, W.W. (1975) Total alkalinity and hardness of surface waters in Alabama and Mississippi. Bulletin No. 465. Auburn, AL. Auburn University/Alabama Agricultural Experimental Station.

Bureau of IndianStandard,BIS.(1991)Waterqualitystandards, Indian Standard for Drinking Water - Specification, Govt of India.

Bureau of Indian Standard, BIS. (1992) Drinking water specification, Draft Indian Standard. Specification, Govt of India.

Bureau of Indian Standard, BIS. (1994) Quality tolerances for freshwater for fish culture, Draft Indian Standard, Bureau of Indian Standard, Govt of India.
Canfield, D.J.Jr. (1983) Prediction of chlorophyll a concentrations in Florida lakes: The importance of phosphorus and nitrogen. Water Resour. Bull. 19, 255-262.

Dillon, P.J. and Rigler, F.H. (1974) The phosphorus chlorophyll relationship in lakes. Limnol. Oceanogr. 19, 767-773.

Edmondson, W.T. (1961) Changes in Lake Washington following an increase in the nutrient income. Verh. Int. Verein. Limnol. 14, 167-175.

Gupta, P.K. and Bhagat, P. (2004) Assemblage of zooplankton community in Lake Naukuchiyatal, a subtropical lake of Kumaun Himalaya, India. Environ. Biol. Conserve. 9, 29-42.

Gupta, R. and Gupta, P.K. (2012) The effect of artificial de-stratification on the water quality of a freshwater high altitude lake. J. Ecophysiol. Occup. HIth. 12, 27-41.

Gupta, P.K. and Pant, M.C. (1990) Distribution and seasonal abundance of benthic macroinvertebrates in Lake Nainital (U.P.), India. Int. Rev. Ges Hydrobiol. 75, 493-506.

Gupta, P.K. and Pant, M.C. (1991) Macrobenthic communities of two Kumaon lakes (U.P., India). In: Ecology of the mountain water (Bhatt and Pande, eds.), 266-275.

Gupta, P.K. and Shukla, U. (1996) Seasonal and spatial distribution of protozoa in a freshwater eutrophic lake of Central Himalaya. Oecologia. Montana. 5, 100-105.

Gupta, R., Bhagat, P., Joshi, M., Inaotombi, S. and Gupta, P.K. (2010) Heavy metal pollution status of Lake Nainital, Uttarakhand. Ind. J. Sci. Res. 1, 15-19.

Gupta, P.K. Nagdali, S. S. and Singh, S. P. (1999) Limnology of lakes. In: Nainital and Kumaon Himalayan Lakes (Singh, S.P. and Gopal Brij, eds.), 38-47.

Hutchinson, G.E. (1957) A Treatise on Limnology. Vol I. Geography, Physics and Chemistry of lakes. John Wiley and Sons, New York.

ICMR, (1963) Manual and Methods for the Examination of Water, Sewage and Industrial waste. Special report, Series No. 14, New Delhi, India

ICMR, (1975) Manual of standards of quality for drinking water supplies. ICMR, New Delhi.

Jones, J.R. and Bachmann, R.W. (1976) Prediction of phosphorus and chlorophyll levels in lakes. J. Water Pollut. Control Fed. 48, 2176-2182.

Joshi, A. (1983) Limnological investigation in Sat Tal Lake, Ph.D. Thesis, Kumaon University, Nainital.

Nagdali, S.S. (2002) Studies on long term changes in pollution and eutrophication of Lake Nainital. Ph.D. Thesis, Kumaon University, Nainital. 
Nagdali, S.S. and Gupta, P.K. (2003) Water quality of an urban drain and nutrient input through it to Lake Nainital, a subtropical hypereutrophic system. Environ. Biol. Conserv. 8, 1-7.

Nagdali, S.S. and Gupta, P.K. (2002) Impact of mass mortality of a mosquito fish, Gambusia affinis on the ecology of a freshwater eutrophic lake (Lake Nainital, India). Hydrobiologia. 468, 45-52.

Negi, V. (1983) Zooplankton population and secondary production in Lake Khurpatal. Ph.D. thesis, Kumaon University, Nainital.

Pant, M.C., Sharma, A.P. and Gupta, P.K., (1979) Trophic status of two lakes of Kumaon. Proc. Symp. Environ. Biol. 203-209.

Pant, M.C. and Joshi, A. (1987) Phytoplankton analysis in Lake Sat Tal (UP, India). Int. Revue ges. Hydrobiol. 3, 307-324.

Pant, M.C., Gupta, P. K., Sharma, P. C. Pande, J. and Sharma, A.P. (1981)Aspects of water pollution in Lake Naini Tal, UP., India. Environ. Conser. 8, 113-117.

Pant, M.C., Joshi, A. and Sharma, P.C. (1985 a) Species composition, temporal abundance and community structure of zooplankton in Lake Sat Tal (UP, India). Arch. Hydrobiol. 102, 519-535.

Pant, M.C., Sharma, A.P., Sharma, P.C. and Gupta, P.K. (1985 b) An analysis of the biotic community in a Kumaon Himalayan Lake, Naini Tal (U.P.), India. Int. Revue. Ges. Hydrobiol. 70, 591-602.

Pant, M.C., Sharma, P.C., Sharma, A.P. and Gupta, P.K. (1985 c) Lake Nainital: An Ecological Perspective. In: Environmental Regeneration in Himalaya: Concepts and Strategies (J.S. Singh ed.). 339-348.

Peterjohn W. T. and Correll D. L. (1984) Nutrient Dynamics in an Agricultural Watershed: Observations on the Role of A Riparian Forest. Ecology. 65, 1466-1475.

Phillipose, M.T. (1960) Freshwater phytoplankton of inland fisheries. Proc. Symp. Algology. 272-291.

Purohit, R. and Singh, S.P. (1985) Submerged macrophytic vegetation in relation to eutrophication level in Kumaun Himalaya, Environmental Pollution Series A, Ecologi and Biologi. 39, 161-174.

Raina, H.S. and Vass, K.K. (1993) Distribution and species composition of zooplankton in Himalayan ecosystems. Int. Rev. Gesamten Hydrobiol. Hydrogr. 78, 295-307.

Russo, R. C. and Thurson, R. V. (1977) The acute toxicity of nitrite to fishes. Recent advances in fish toxicology. Ecological Research Series, EPA-600/3-77-085.

Schindler, D. W. (1987) Detecting ecosystem responses to anthropogenic stress. Can. J. Fish. Aquat. Sci. 49, 6-25.
Sedaghat, S. and Hoseini, S.A. (2012) Variations in Water Quality Parameters of Ala-Gol Wetland in Golestan Province, Iran. Middle-East. J. Sci. Res. 12, 402-405.

Sharma, A.P., Jaiswal, S., Negi, V. and Pant, M.C. (1982) Phytoplankton community in lakes of Kumaon Himalaya. Arch. Hydrobiol. 93, 173-193.

Shukla, U. and Gupta, P.K. (2001) Assemblage of ciliated protozoan community in a polluted and non-polluted environment in a subtropical lake of Central Himalayas: Lake Nainital, India. J. Plankton Res. 23, 571-584.

Singh, S.P. (1981) Physico-chemical characteristics and macrophytes of Naukuchiya Tal, a mid altitude lake of Kumaon Himalaya (India). Trop. Ecol. 22, 40-53.

Singh, S.P., Pant, M.C., Sharma, A.P., Sharma, P.C. and Purohit, R. (1982) Limnology of shallow Water zones of lakes in Kumaon Himalaya (India). Wetland: Ecology and management. Proc. First. Int. Wetland Conf. 39-49.

Smith, V.H. (1982) The nitrogen and phosphorus dependence of algal biomass in lakes: A theoretical and empirical analysis. Limnol. Oceanogr. 27, 1101-1112.

Smith, V.H. (1986) Light and nutrient effects on the relative biomass of blue-green algae in lake phytoplankton. Can. J. Fish. Aquat. Sci. 43, 148-153.

Smith, V.H., Tilman G.D. and Nekola J.C. (1999) Eutrophication: impacts of excess nutrient inputs on freshwater, marine, and terrestrial ecosystems. Environ. Pollut. 100, 179-196.

Talling, J.F. (1971) The underwater light climate as controlling factor in the production ecology of freshwater phytoplankton. Mitt. Int. ver. Limnl. 19, 214-243.

Tilman, D., Kilham, S.S. and Kilham, P. (1982) Phytoplankton Community Ecology: The Role of Limiting Nutrients. Annu. Rev. Ecol. Syst. 13, 349-372.

U.S. EPA. (1976) Quality Criteria for Water. EPA - 440/9 - 76 - 023, United States Environmental Protection Agency, Washington, D. C.

Vollenweider, R.A. (1968) Scientific fundamentals of the eutrophication of lakes and flowing waters with particular reference to nitrogen and phosphorus as factors in eutrophication. Report: Organisation for Economic Co-operation and Development, Directorate of Scientific Affairs, Paris.

Welch, P.S. (1948) Limnological Methods. McGraw Hill Book Company Inc. New York.

Wetzel, R.G. (1975) Limnology 1st ed. W.B. Saunders Co. Philadelphia, USA.

Wetzel, R.G. and Likens, G.E. (1979) Limnological Analysis. W. B. Saunders Co. Philadelphia. 
Wetzel, R.G. (2001) Limnology. Lake and River Ecosystems. Academic Press, San Diego.

WHO/UNEP. (1996 a) Water Quality Monitoring. A practical guide to the design and implementation of freshwater quality studies and monitoring programmes, First edition, $E$ and FN Spon, an imprint of Chapman and Hall, 2-6 Boundary Row, London, UK

WHO/UNEP. (1996 b) Water Quality Assessments - A Guide to Use of Biota, Sediments and Water in Environmental Monitoring. Second Edition, E \& FN, Chapman \& Hall, 2-6 Boundary Row, London, UK
WHO/UNEP. (1997) Water Pollution Control - A Guide to the Use of Water Quality Management Principles, In: Richard Helmer and Ivanildo Hespanhol eds. The Water Supply \& Sanitation by E. and F. Spon. Chapman and Hall, 2-6 Boundary Row, London, UK.

Woltemade, C.J. (2000) Ability of restored wetlands to reduce nitrogen and phosphorus concentrations in agricultural drainage water. J. Soil Water Conserv. 55, 303-309. 